\title{
THE EFFECT OF ACHENE HETEROMORPHISM ON PROGENY TRAITS IN THE SHAGGY SOLDIER [Galinsoga ciliata (RAFIN) S. F. BLAKE]
}

\author{
Magdalena Kucewicz $^{1}$, Ewa Gojło ${ }^{2}$, Anna Kowalska ${ }^{1}$ \\ ${ }^{1}$ Department of Botany and Nature Protection, University of Warmia and Mazury, Plac Łódzki 1, 10-718 Olsztyn, Poland \\ ${ }^{2}$ Department of Plant Physiology and Biotechnology, University of Warmia and Mazury \\ Oczapowskiego 1a, 10-718 Olsztyn, Poland \\ e-mail: magdo@moskit.uwm.edu.pl
}

Received: 20.06 .2010

\section{Abstract}

The shaggy soldier [Galinsoga ciliata (Rafin) S. F. Blake], family Asteraceae] is an invasive species that poses a growing threat to crop production. This annual plant produces heteromorphic achenes in a capitulum type inflorescence. The objective of this study was to compare selected morphological and phenological parameters and the success of generative reproduction in plants developed from peripheral and central achenes of the capitulum. The somatic variability of $G$. ciliata diaspores contributed to differences in the growth rates, development and fertility of the resulting populations. The progeny of central diaspores developed at a slower rate than the individuals derived from peripheral achenes, but at the end of their life cycle, the offspring of dimorphic achenes formed homogenous groups as regards height values. On average, the initial phenophases of G. ciliata plants derived from central achenes began one day later, and they entered the flowering stage eight days later than the individuals developed from peripheral seeds. At the initial growth stage (experimental day 65 to 83), the progeny of central achenes produced fewer capitula. On day 133, the individual fertility of the plants derived from central diaspores was $10 \%$ higher on average in comparison with the offspring of peripheral achenes.

Key words: Galinsoga ciliata, heteromorphism, achenes, generative reproduction, growth, phenology

\section{INTRODUCTION}

Heteromorphism promotes the development of various ecological strategies of evolutionary significance. The production of seeds and fruits with different dispersal capacity, dormancy patterns and germination requirements is a specific feature of that strategy which enables species to survive under variable and unpredictable environmental conditions (I m bert, 2002; Matilla et al. 2005; Ven ab le, 1985).
In plants of the family Asteraceae, heteromorphism is manifested by the formation of two types of achenes in the inflorescence (capitulum): peripheral achenes in the outer whorl and central achenes situated above (R o ch a, 1996; Venable and Levin, 1985a). In many species, achenes differ with regard to their size, shape, mass, depth of dormancy, germination and dispersion ability (B a skin and B a skin, 1998; Corkidi et al. 1991; Flint and Palmblad, 1978; I m ber t , 2002; I m bert et al. 1996; R o c ha, 1996; T a n owitz et al. 1987).

Selected representatives of Asteraceae adopt the strategy of weak dispersion and delayed germination of weakly dispersed peripheral achenes as well the strategy of strong dispersion, faster and fuller germination of widely dispersed central achenes ( $\mathrm{R}$ o c h a , 1996; Tanowitz et al. 1987, Venable et al. 1987). The above strategies are not obligatory in all species. In some cases, the morphological differentiation of achenes is related to dispersion polymorphism, but it does not result in germination variability. Weakly dispersed achenes have also been found to germinate more rapidly and fully than widely dispersed diaspores (Chmielewski, 1999; E1lner, 1986, I m bert et al. 1996, Pitel k a et al. 1983).

Whereas the dispersion ability, dormancy and germination of heteromorphic Asteraceae has been thoroughly researched, the progeny of heteromorphic diaspores remains poorly documented. In selected heteromorphic species, seed size affects the size and viability of seedlings, thus contributing to their competitive advantage and reproductive output at later stages of life (I m bert, 2002; R a i and Tripath i, 1987; Venable and Levin, 1985b; Venable et al. 1987). In selected annual plants of the family Asteraceae, achene mass is positively correlated with seed embryo size. In other species, the higher mass of 
peripheral achenes is attributed to the specific pericarp structure which plays an important role in germination, in particular water absorption by embryonic tissue and gaseous exchange (E l - K e b l a w y , 2003; I m b e r t, 2002; Imbert et al. 1997; Ruiz De Clavijo and J i m é n e z, 1998). The effect of seed heteromorphy on growth, development and generative reproduction was investigated in very few species (E $1 \mathrm{Ke} \mathrm{b}$ l a w y, 2003; I m b e r t et al. 1997; 1996).

The objective of this study was to examine the progeny traits of the shaggy soldier, Galinsoga ciliata (Rafin) S. F. Blake (family Asteraceae), derived from heteromorphic diaspores, and to compare selected morphological and phenological parameters and the success of generative reproduction in plants developed from peripheral and central achenes.

\section{MATERIALS AND METHODS}

\section{Species}

The shaggy soldier [Galinsoga ciliata (Rafin) S. F. Blake], a popular weed of root crops, grain crops and stubble fields, is an invasive species that easily colonizes new territories. It is a widely propagating and an increasingly aggressive species that poses a growing threat to crop production in Poland (K o r n i a k, 1997; 1992; Trzcińs k a - T a cik et al. 2009).

\section{Achenes}

The experimental materials comprised mature achenes of G. ciliata collected on 20 September 2004 from a weed population in carrots grown in the Experimental Garden of the University of Warmia and Mazury in Olsztyn $\left(53^{\circ} 78^{\circ} \mathrm{N}\right.$ latitude and $20^{\circ} 49^{\circ} \mathrm{E}$ longitude), on heavy loamy sand soil deposited on a light loamy layer, of quality class IIIa. On the next day after harvest, the achenes were divided into two groups based on their position in the inflorescence. Two distinct types of achenes are produced on the same receptacle. One type, formed from central florets, is characterized by a pappus-scales aristate; the other type, formed from peripheral florets, has a strongly reduced pappus (K u l p a , 1988).

\section{Experiment}

The experiment was carried out in the greenhouse of the Experimental Garden of the University of Warmia and Mazury in Olsztyn. G. ciliata achenes were sown on 3 December 2004. 10 seedlings per achene type were planted in pots filled with substrate (50\% sterile soil, $50 \%$ compost). Greenhouse temperature was maintained at $22-24^{\circ} \mathrm{C}$ during the day and 15 $18^{\circ} \mathrm{C}$ at night. The beginning of selected phenophases was determined from the sowing date. Plant height was measured on day 31, 41, 51, 65 and 133 after emergence. The number of capitula and seeds per capitulum was determined at various stages of development. The collected data were used to estimate individual fertility. The experiment was terminated 133 days after emergence.

\section{RESULTS}

G. ciliata plants derived from central and peripheral achenes were characterized by various growth rates. The plants from central achenes developed at a slower rate than the progeny of peripheral achenes. On observation day 65, their average height was lower by approximately $6 \mathrm{~cm}$, and on day 133, the differences in height were leveled out between the studied morph groups (Table 1, Figs 1, 2, 3).

The initial phenophases in plants derived from central achenes commenced one day later in comparison with the individuals developed from peripheral achenes. Significant differences were noted in respect of the time of first flowering, and the progeny of central achenes began to flower eight days later than the individuals derived from peripheral achenes (Table 2 ). The above resulted in lower fertility values of the offspring of central achenes (number of capitula per plant) on day 65 and 83 . On day 83, the progeny of central achenes produced approximately 50 fewer capitula in comparison with the plants derived from peripheral achenes. Between days 83 and 133, a visible increase in the reproductive effort of plants from central achenes was observed. On day 133, they produced approximately 28 more capitula, and each capitulum contained more achenes than in the progeny of peripheral achenes. Individual fertility values were higher in the offspring of central achenes by approximately $10 \%$ on the last day of the experiment (Table 1).

\section{DISCUSSION}

The effect of achene heteromorphism on the growth and reproduction of Asteraceae plants has been scarcely investigated. The existing studies indicate that the progeny traits of heteromorphic achenes differ subject to species and environmental conditions (I mbert et al. 1996, B e neke et al. 1993, Venable and Levin, 1985b). Research results suggest that heteromorphic $G$. ciliata diaspores produce progeny marked by different growth patterns over time. On average, the initial phenophases of $G$. ciliata plants derived from central achenes began one day later in comparison with the progeny of peripheral achenes (Table 2). According to S y m o n i d e s (1977), under the fluctuating conditions of natural habitats, this slight reduction could be sufficient to lead to great differences in survival. Significant differences were noted as regards first flowering dates. The plants developed from 
Table 1

Characteristics of growth and reproduction of Galinsoga ciliata plants from the peripheral and central achenes at different post-emergence times

\begin{tabular}{|c|c|c|c|c|c|c|c|}
\hline \multirow{2}{*}{ Parameters } & \multirow{2}{*}{$\begin{array}{c}\text { Time after } \\
\text { emergence } \\
\text { [days] }\end{array}$} & \multicolumn{3}{|c|}{ Peripheral } & \multicolumn{3}{|c|}{ Central } \\
\hline & & Mean & Min & Max & Mean & Min & Max \\
\hline \multirow{5}{*}{ Height $[\mathrm{cm}]$} & 31 & 3.4 & 3.1 & 4.2 & 3.2 & 2.8 & 5.1 \\
\hline & 41 & 6.1 & 5.2 & 7.5 & 4.9 & 4.2 & 5.4 \\
\hline & 51 & 12.4 & 10.2 & 16.1 & 9.5 & 7.4 & 11.2 \\
\hline & 65 & 23.3 & 20.1 & 26.0 & 17.5 & 14.2 & 20.4 \\
\hline & 133 & 64.4 & 58.1 & 70.0 & 61.0 & 56.0 & 66.0 \\
\hline \multirow{3}{*}{ Number of capitulum/plant } & 65 & 15 & 5 & 21 & 3 & 2 & 6 \\
\hline & 83 & 130 & 120 & 142 & 80 & 44 & 102 \\
\hline & 133 & 251 & 163 & 270 & 279 & 201 & 348 \\
\hline \multirow{2}{*}{$\begin{array}{c}\text { Number of peripheral } \\
\text { achenes/capitulum }\end{array}$} & 83 & 5.0 & 5 & 5 & 4.9 & 4 & 5 \\
\hline & 133 & 4.3 & 4 & 5 & 4.4 & 4 & 5 \\
\hline \multirow{2}{*}{$\begin{array}{l}\text { Number of central } \\
\text { achenes/capitulum }\end{array}$} & 83 & 25.0 & 24 & 27 & 25.9 & 24 & 28 \\
\hline & 133 & 19.2 & 15 & 26 & 20.9 & 17 & 24 \\
\hline \multirow{2}{*}{ Number of achenes/capitulum } & 83 & 30.0 & 29 & 32 & 30.8 & 28 & 33 \\
\hline & 133 & 23.6 & 19 & 31 & 25.3 & 21 & 29 \\
\hline \multirow{2}{*}{ Number of achenes/plant } & 83 & 3900 & 3600 & 4260 & 2464 & 1355 & 3141 \\
\hline & 133 & 6856 & 4614 & 7280 & 7648 & 5327 & 9365 \\
\hline
\end{tabular}

Table 2

The beginning of selected phenophases in Galinsoga ciliata plants derived from peripheral and central achenes (days \pm SE)

\begin{tabular}{lcc}
\hline \multirow{2}{*}{ Life history } & \multicolumn{2}{c}{ Days after sowing } \\
\cline { 2 - 3 } & Peripheral & Central \\
\hline Cotyledon emergence & $7 \pm 0.00$ & $8 \pm 0.00$ \\
2-leaf stage & $21 \pm 0.00$ & $22 \pm 0.00$ \\
4-leaf stage & $27 \pm 0.10$ & $28 \pm 0.16$ \\
Time of first flowering & $59.5 \pm 0.96$ & $67 \pm 1.10$ \\
\hline
\end{tabular}

peripheral achenes entered this growth stage eight days earlier than the offspring of central seeds. A similar pattern was observed in Galinsoga parviflora plants produced from peripheral achenes which flowered 15 days earlier than the progeny of central achenes in soils fertilized with low NPK rates. Nutrient abundance was also an important consideration, and the progeny of both morph types flowered simultaneously in soils fertilized with average and high NPK levels (R a i and Tripathi, 1987). In dimorphic populations of Crepis sancta, the plants derived from peripheral diaspores were characterized by higher viability, larger embryos and seedlings in comparison with the progeny of central achenes. Despite the above, pheno- logical observations of $C$. sancta did not validate the significance of achene morphology on plant growth (I m b e r t et al. 1996).

In this experiment, the progeny of the shaggy soldier derived from peripheral achenes was marked by faster growth rates until day 65 . Between days 65 and 133, the growth of individuals derived from central diaspores was accelerated. On the last day of the experiment, G. ciliata plants developed from peripheral achenes were characterized by higher average height in comparison with the progeny of central achenes, but the distribution of values leveled out the differences between the offspring of different morph types. Mature individuals formed homogenous populations 


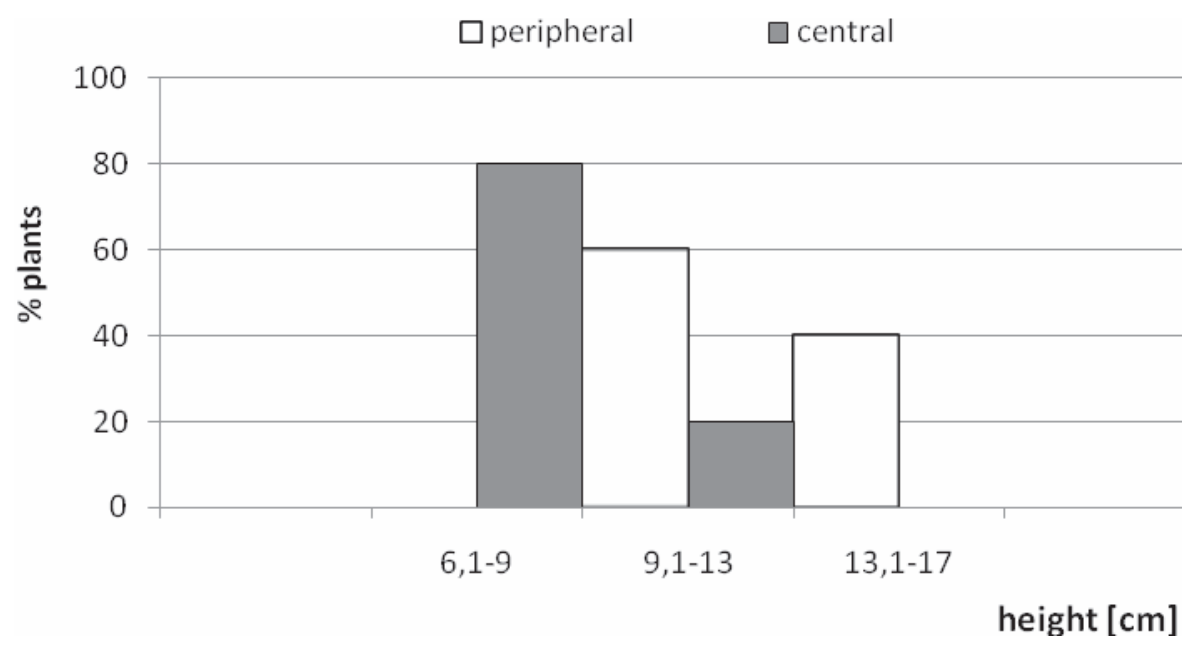

Fig. 1. The height $[\mathrm{cm}]$ of Galinsoga ciliata plants derived from peripheral and central achenes on experimental day 51

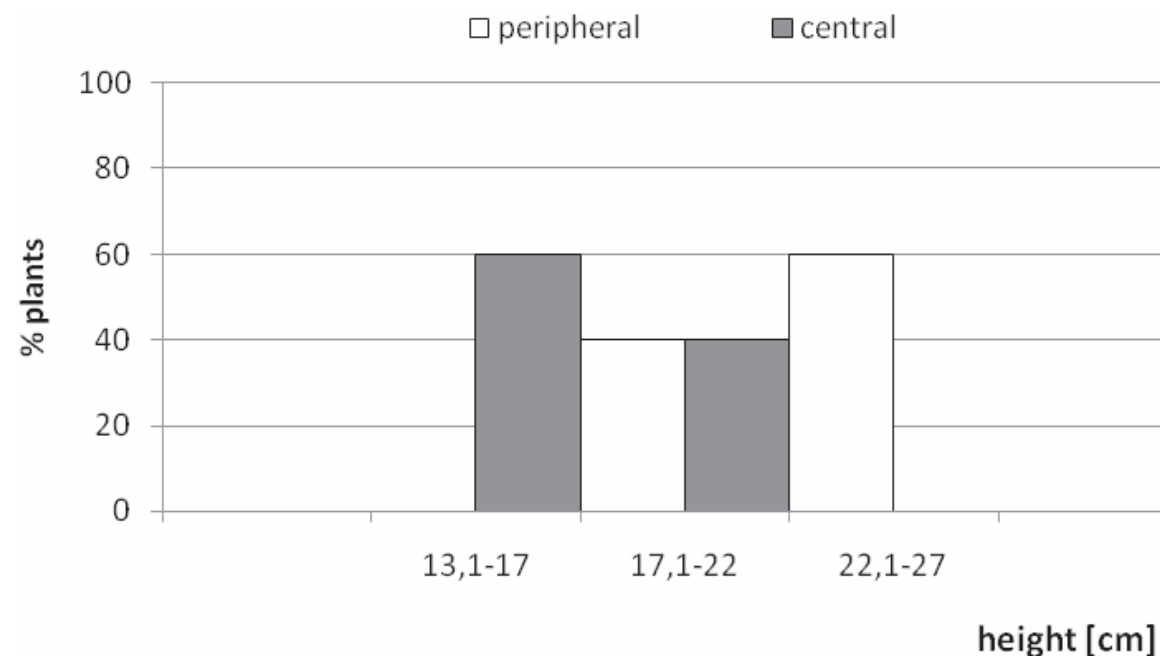

Fig. 2. The height $[\mathrm{cm}]$ of Galinsoga ciliata plants derived from peripheral and central achenes on experimental day 65

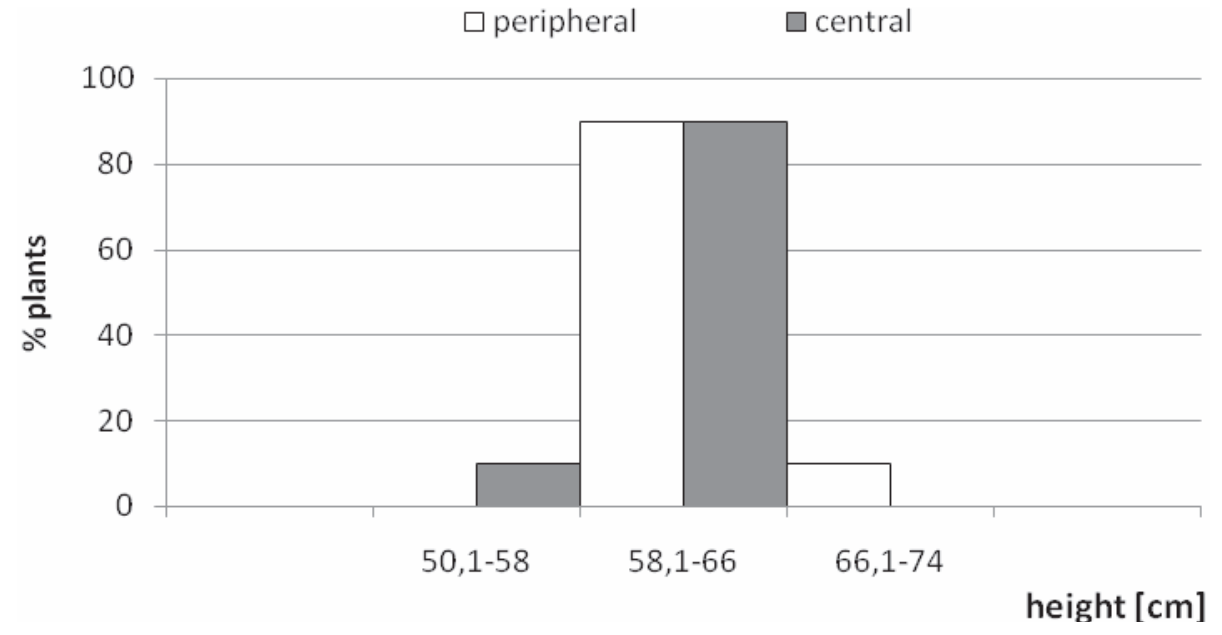

Fig. 3. The height [cm] of Galinsoga ciliata plants derived from peripheral and central achenes on experimental day 133 
regardless of achene heteromorphism (Table 1, Figs 1, 2, 3). As regards Crepis aspera, seed morphology did not affect plant growth or height values in successive days of the experiment. In Hedypnois cretica populations, no differences were noted in the initial phenophases, and the height of individuals produced by dimorphic fruit was differentiated at successive growth stages (E l - K e b l a w y, 2003).

The somatic variability of G. ciliata diaspores contributed to significant differences in plant development. The individuals produced by central achenes were marked by slower growth rates and delayed onset of flowering, but their reproductive effort was intensified at later stages between days 83 and 133. During this period, the capitula of plants derived from central diaspores produced more achenes than the progeny of peripheral diaspores. The ultimate individual fertility of central plants was approximately $10 \%$ higher in comparison with peripheral plants (Table 1,2). G. parviflora individuals developed from peripheral achenes were marked by higher fertility values (number of capitula and number of seeds per plant) than the progeny of central achenes (at low and average NPK concentrations) (R a i and Tripath i, 1987). H. cretica plants derived from peripheral diaspores produced a higher number of inflorescences than individuals developed from central achenes (E $1-K e b l a w y, 2003)$. The progeny of $C$. aspera and $C$. sancta grown from heteromorphic achenes produced similar numbers of capitula (E 1 Keblawy, 2003, I mbert et al. 1996). In G. ciliata, the morphological and phenological differences between the progeny of various morph types were manifested at different stages of life. According to E 1 - K e blaw y (2003), dimorphic features continue to affect individual traits at every developmental phase.

\section{CONCLUSIONS}

1. The somatic variability of G. ciliata diaspores contributed to differences in the growth rates, development and fertility of the resulting populations. The morphological and phenological differences between the progeny of various morph types were manifested at different stages of life

2. Differences were noted in the growth rates of G. ciliata plants derived from central and peripheral achenes. The progeny of central diaspores developed at a slower rate than the individuals derived from peripheral achenes, but at the end of their life cycle, the offspring of dimorphic achenes formed homogenous groups as regards height values.

3. On average, the initial phenophases of G. ciliata plants derived from central achenes began one day later, and they entered the flowering stage eight days later than the offspring of peripheral diaspores.
4. At the initial growth stage between experimental day 65 and 83, the progeny of central achenes produced fewer capitula. Past day 83, those plants significantly maximized their reproductive effort (producing more capitula with a higher number of seeds per inflorescence). On day 133, the individual fertility of the plants derived from central diaspores was $10 \%$ higher on average in comparison with the offspring of peripheral achenes.

\section{REFERENCES}

B a sk in J. M., B a skin C. C., 1998. Seeds. Ecology, biogeography and evolution of dormancy and germination. Academic Press. New York.

Beneke K., van Rooyen M. W., Theron G. K., van de Venter H. A., 1993. Fruit polymorphism in ephemeral species of Naquamaland. IV. Growth analyses of plant cultivated from the dimorphic diasporas. J. Arid Environ. 24: 345-360.

Chmielewski J. G., 1999. Consequences of achene biomass, within-achene allocation patterns, and pappus on germination in ray and disc achenes of Aster umbellatus var. umbellatus (Asteraceae). Can. J. Bot. 77: 426-433.

Corkidi L., Rincon E., Vazquez-Yanes C., 1991. Effects of light and temperature on germination of heteromorphic achenes of Bidens odorata (Asteraceae). Can. J. Bot. 69: 574-579.

E1-Keblawy A., 2003. Effects of achene dimorphism on dormancy and progeny traits in the two ephemerals $\mathrm{He}$ dypnois cretica and Crepis aspera (Asteraceae). Can. J. Bot. 81: 550-559.

El1ner S., 1986. Germination dimorphism and parentoffspring conflict in seed germination. J. Theor. Biol. 123: $173-185$.

Fl in t S. D., P a $1 \mathrm{~m}$ bl a d I. G., 1978. Germination dimorphism and developmental flexibility in the ruderal weed Heterotheca grandiflora. Oecol. 36: 33-43.

I mbert E., 2002. Ecological consequences and ontogeny of seed heteromorphism. Perspect. Plant Ecol., Evol. Syst. 5: 13-36

I mbert E., Es carré J., Lepart J., 1996. Achene dimorphism and among - population variation in Crepis sancta (Asteraceae). Int. J. Plant Sci. 157: 309-315.

Imbert E., Escarré J., Lepart J., 1997. Seed heteromorphism in Crepis sancta (Asteraceae): performance of two morphs in different environments. Oikos, 79: 325-332.

Korniak T., 1992. Flora segetalna północno-wschodniej Polski, jej przestrzenne zróżnicowanie i współczesna przemiany. / Segetal flora of north-eastern Poland, its spatial differentiation and current changes. Acta Acad. Agricult. Techn. Olst. Agricultura, 53: 1-76 (in Polish).

Korniak T., 1997. Współczesne przemiany flory segetalnej w północno-wschodniej Polsce. / Current changes in segetal flora in north-eastern Poland. Ogólnopolska 
Konferencja Naukowa. Doskonalenie Technologii Produkcji Roślin Warzywnych. XVI Spotkanie Zespołu Herbologicznego Komitetu Nauk Ogrodniczych PAN. Olsztyn 24-25 June 1997: 1-9 (in Polish).

Kulpa W., 1988. Nasionoznawstwo chwastów. / Weed seed science. Państwowe Wydawnictwo Rolnicze i Leśne, Warszawa (in Polish).

Matilla A., Gallardo M., Puga-Hermida M. I., 2005. Structural, physiological and molecular aspects of heterogeneity in seeds: a review. Seed Sci Res., 15: 63-76.

Pitelka L. F., Thayer M. E., Hansen S. B., 1983. Variation in the achenes weight in Aster acuminatus. Can. J. Bot. 61: 1415-1420.

Ra i J. P. N., Tripathi R. S., 1987. Germination and plant survival and growth of Galinsoga parviflora Cav. as related to food and energy content of its ray- and discachenes. Acta Ecol. 8 (22): 155-165.

Rocha O. J., 1996. The effects of achene heteromorphism on the dispersal capacity of Bidens pilosa L. Int. J. Plant Sci, 157: 316-322.

Ruiz De Clavijo E., Ji ménez M. J., 1998. The influence of achene type and plant density on growth and biomass allocation in the heterocarpic annual Catananche lutea (Asteraceae). Int. J. Plant. Sci. 159: 637-647.

S y monides E., 1977. Mortality of seedlings in natural psammophyte populations. Ekol. Pol. 25: 635-651.

Tanowitz B. D., Salopek P. F., Mahall B. E., 1987. Differential germination of ray and disk achenes in $\mathrm{He}$ mizonia increscens (Asteraceae). Am. J. Bot. 74: 303312.

Trzcińska-Tacik H., Puła J., Stokłosa A., Malara J., S tępni k K., 2009. Ekspansja gatunków z rodzaju Galinsoga i Avena fatua w zbiorowiskach chwastów polnych w dolinie Wisły powyżej Krakowa. / Expansion of the species of the genera Galinsoga and Avena fatua in field weed communities in the Vistula River valley upstream of Kraków. XXXIII Konferencja Naukowa z cyklu „Rejonizacja chwastów segetalnych w Polsce”, Siedlce (Poland) 3-4 September, 2009: 52 (in Polish).

Venable D. L., 1985. The evolutionary of seed heteromorphism. Am. Nat.: 577-595.

Venable D. L., Burquez A., Corral G., Morales E., Espinosa F., 1987. The ecology of seed heteromorphism in Heterotheca pinatum in central Mexico. Ecology 68: 65-76.

Venable D. L., Levin D. A., 1985a. Ecology of achene dimorphism in Heterotheca latifolia. I. Achene structure, germination and dispersal. J. Ecol. 73: 133-145.

Venable D. L., Levin D. A., 1985b. Ecology of achene dimorphism in Heterotheca latifolia. II. Demographic variation within populations. J. Ecol. 73: 743-755.

\section{Wpływ heteromorfizmu niełupek na kiełkowanie oraz wzrost i rozwój żółtlicy owłosionej [Galinsoga ciliata (Rafin) S.F. Blake]}

\section{Streszczenie}

Żółtlica owłosiona [Galinsoga ciliata (Rafin) S.F. Blake, Asteraceae] jest gatunkiem inwazyjnym, stanowiącym poważne zagrożenie na wielu polach uprawnych. Jest rośliną jednoroczną, która w kwiatostanie typu koszyczka wytwarza heteromorficzne niełupki. Celem niniejszej pracy było porównanie wybranych cech morfologicznych, fenologii i poziomu reprodukcji generatywnej roślin pochodzących z brzeżnych i środkowych niełupek. Zróżnicowanie somatyczne diaspor wpływało na wytworzenie populacji zróżnicowanej pod względem tempa wzrostu, rozwoju i płodności. Okazy z niełupek centralnych rosły wolniej niż okazy z niełupek brzeżnych, ale pod koniec cyklu życiowego rośliny z dymorficznych niełupek utworzyły jednorodne grupy pod względem wysokości. Początkowe fazy rozwojowe roślin z niełupek centralnych rozpoczynały się średnio o jeden dzień później, natomiast początek kwitnienia miał miejsce o osiem dni później niż u okazów z nasion brzeżnych. W początkowym okresie rozwoju (w 65 i 83 dniu obserwacji) rośliny $\mathrm{z}$ niełupek centralnych wytwarzały mniej koszyczków. Po tym okresie następowało znaczne zwiększenie wysiłku reprodukcyjnego roślin z niełupek centralnych, które wytwarzały więcej koszyczków, a w koszyczku miały więcej niełupek niż rośliny $\mathrm{z}$ niełupek brzeżnych. Ostatecznie płodność osobnicza roślin z niełupek centralnych była wyższa o ok. $10 \%$ od płodności osobniczej roślin z niełupek brzeżnych. 